DIGITALISASI PEMBELAJARAN PENDIDIKAN JASMANI DI ERA 4.0
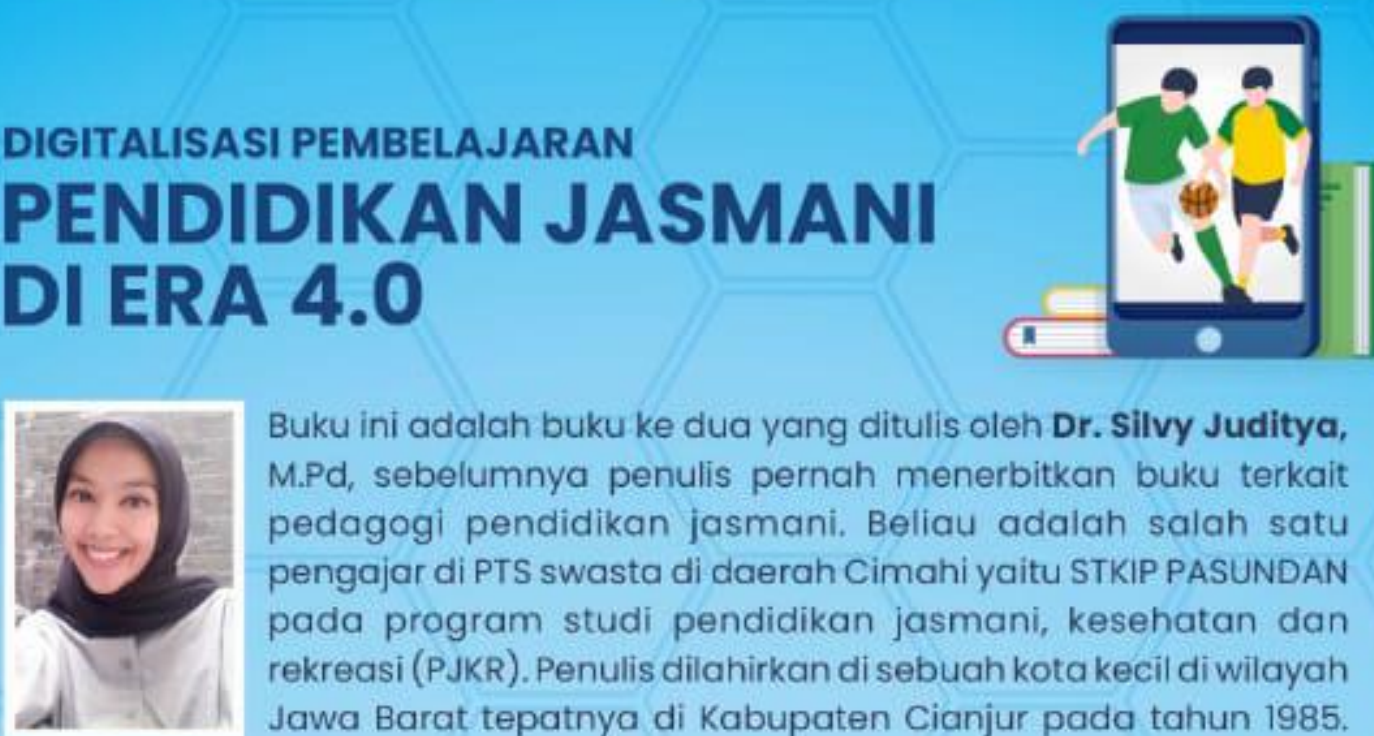

Buku ini adalah buku ke dua yang ditulis oleh Dr. Silvy Juditya, M.Pd, sebelumnya penulis pernah menerbitkan buku terkait pedagogi pendidikan jasmani. Beliau adalah salah satu pengajar di PTS swasta di daerah Cimahi yaitu STKIP PASUNDAN pada program studi pendidikan jasmani, kesehatan dan rekreasi (PJKR). Penulis dilahirkan di sebuah kota kecil di wilayah Jawa Barat tepatnya di Kabupaten Cianjur pada tahun 1985. Penulis menempuh pendidikan tinggi di salah satu PTN ternama di kota Bandung yaitu Universitas Pendidikan Indonesia, penulis memperoleh gelar sarjana di Fakultas Pendidikan Olahraga dan Kesehatan (FPOK) program studi Pendidikan Kepelatihan Olahraga (PKO) mulai dari tahun 2003-2007, beliau melanjutkan studi magisternya masih di UPI tepatntya di Sekolah Pasca Sarjana Program studi Pendidikan Olahraga tahun 2008-2010 dan di tahun 2016 beliau melanjutkan kembali studinya dan masih sama di SPS UPI program studi pendidikan Olahraga dan berhasil menyelesaikan studi di tahun 2020.

Era 4.0 yang terjadi saat ini memberikan banyak perubahan, dimana dampak perubahan itu terlihat dari adanya pola pembelajaran yang berbeda pada generasi saat ini. Pola pembelajaran yang ada pada era 4.0 sangat kental dengan unsur penggunaan teknologi di dalamnya, bahkan di era 4.0 saat ini perubahan yang terjadi pada proses pembelajaran diantaranya pemanfaatan berbagi media pembelajaran berbasis teknologi untuk menunjang pembelajaran sampai pada pembelajaran yang lebih bersifat individu. Perubahan tersebut ikut memberikan warna baru pada pembelajaran Pendidikan Jasmani, Olahraga dan Kesehatan (PJOK) di setiap satuan pendidikan yang ada, maka dari itu di dalam buku ini menjelaskan terkait perkembangan/perubahan pembelajaran pendidikan jasmani di era digital, aplikasi yang mampu mensupport pembelajaran, model pembelajaran berbasis individualized learning dan aspek karakter siswa yang harus menjadi perhatian guru PJOK dalam memilih dan menerapkan media pembelajaran serta model pembelajaran yang nantinya mampu memberikan dampak pada pembelajaran PJOK yang jauh lebih menyenangkan dan membuat mereka nyaman dengan situasi pembelajaran yang ada khususnya di era digitalisasi 4.0 ini.

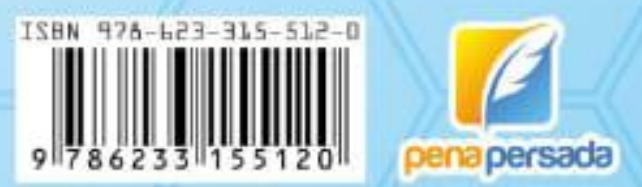

Dr. Silvy Juditya, M.Pd

\section{DIGITALISASI PEMBELAJARAN} PENDIDIKAN JASMANI DI ERA 4.0

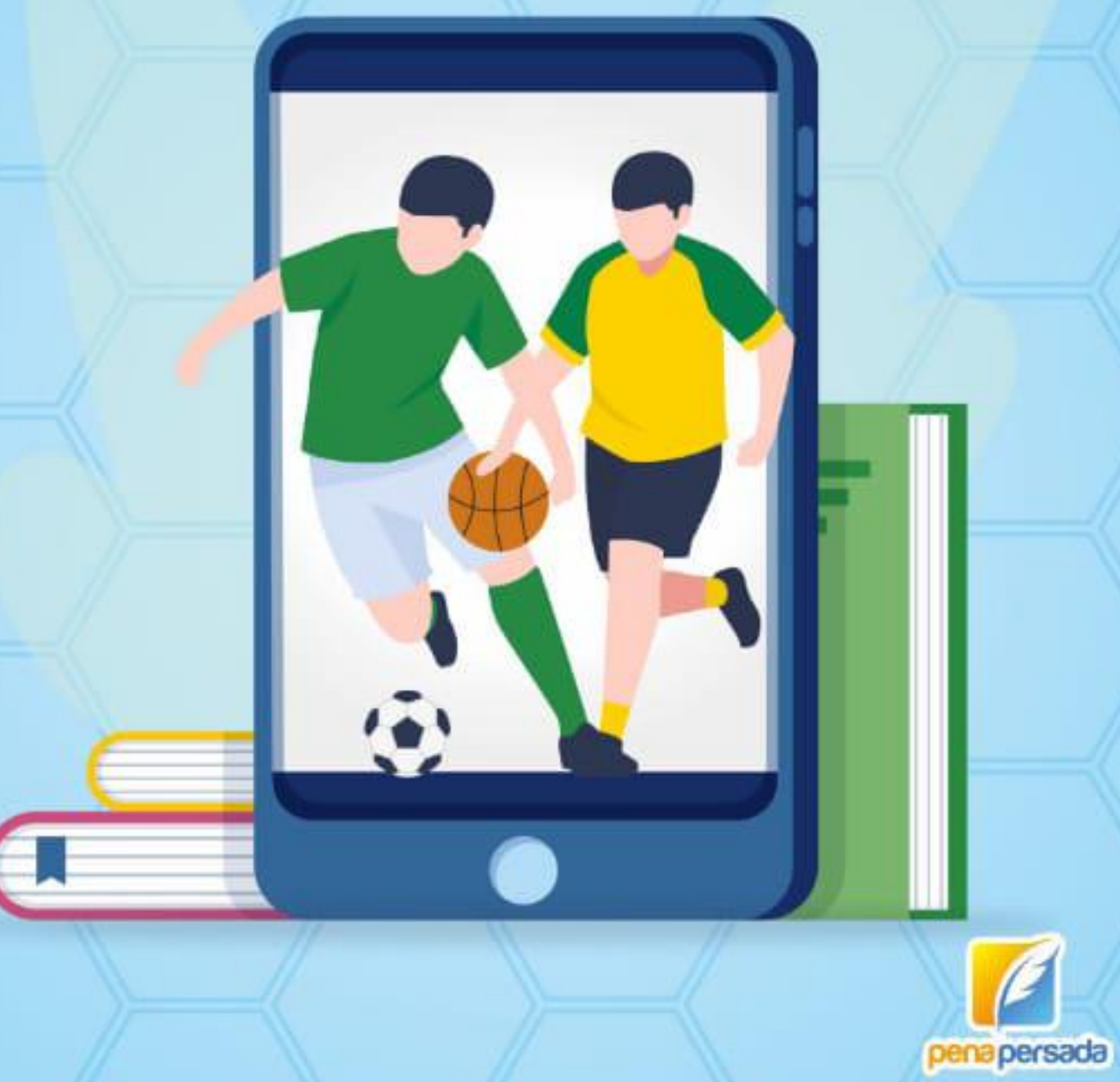




\title{
DIGITALISASI PEMBELAJARAN \\ PENDIDIKAN JASMANI DI ERA 4.0
}

\author{
Dr. Silvy Juditia, M.Pd
}

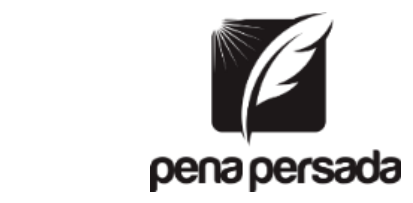

PENERBIT CV. PENA PERSADA 


\title{
DIGITALISASI PEMBELAJARAN PENDIDIKAN JASMANI
}

DI ERA 4.0

\author{
Penulis: \\ Dr. Silvy Juditia, M.Pd \\ ISBN : 978-623-315-512-0
}

Editor:

Wiwit Kurniawan

Design Cover :

Retnani Nur Briliant

Layout :

Eka Safitry

\section{Penerbit CV. Pena Persada \\ Redaksi :}

Jl. Gerilya No. 292 Purwokerto Selatan, Kab. Banyumas

Jawa Tengah

Email : penerbit.penapersada@gmail.com

Website : penapersada.com Phone : (0281) 7771388

Anggota IKAPI

\author{
All right reserved \\ Cetakan pertama : 2020
}

Hak Cipta dilindungi oleh undang-undang. Dilarang memperbanyak karya tulis ini dalam bentuk apapun tanpa izin penerbit 


\section{KATA PENGANTAR}

Segala puji senantiasa kita panjatkan kehadirat Allah Swt, atas segala rahmat dan karunianya, akhirnya penulis dapat menyelesaikan penyusunan buku yang berjudul "DIGITALISASI PEMBELAJARAN PENDIDIKAN JASMANI DI ERA 4.0". Saya menyadari bahwa tanpa bantuan dan bimbingan dari berbagai pihak sangatlah sulit bagi saya untuk menyelesaikan karya ini. Oleh karena itu, saya mengucapkan banyak terima kasih pada semua pihak yang telah membantu penyusunan buku ini. Sehingga buku ini bisa hadir di hadapan pembaca.

Pendidikan jasmani merupakan bagian dari proses pendidikan secara keseluruhan bahkan sebagai suatu konsep latihan atau sebagai pengajaran gerak, secara sederhana penjas adalah proses belajar yang bertujuan untuk belajar melalui gerak dengan demikian anak akan mampu menggunakan tubuhnya secara efisien yang didasarkan pada pemahamannya mengenai aktivitas yang melibatkan tubuh. Pengaruh lain dari proses belajar pendidikan jasmani kepada anak di sekolah adalah menumbuhkan pemahaman dan pembiasaan untuk mau melibatkan tubuh melakukan aktivitas gerak dengan berbagai keterampilan pada banyak kegiatan olahraga untuk dapat memelihara kebugaran jasmaninya. Dalam buku ini akan membahas tentang pendidikan jasmani di era digitalisasi berbasis individualized learning.

Penulis menyadari bahwa buku ini masih jauh dari kesempurnaan. Oleh karena itu kritik dan saran yang membangun sangat dibutuhkan guna penyempurnaan buku ini. Akhir kata saya berharap Allah Swt berkenan membalas segala kebaikan semua pihak yang telah membantu

Penulis 


\section{DAFTAR ISI}

KATA PENGANTAR iii

DAFTAR ISI iv

BAB I PENDAHULUAN 1

A. Perkembangan Pembelajaran Pendidikan Jasmani 1

B. Model Pembelajaran Yang Effektif 6

BAB II PENDIDIKAN JASMANI 13

A. Hakikat Pendidikan Jasmani 13

B. Tujuan Pendidikan Jasmani 15

C. Hasil Belajar dalam Pembelajaran Pendidikan $\begin{array}{ll}\text { Jasmani } & 17\end{array}$

BAB III PERMAINAN BOLA BESAR 19

A. Permainan Bola Basket 19

1. Hakekat Permainan Bola Basket 19

2. Teknik Dasar pada Permainan Bola Basket 20

3. Passing 21

4. Dribbling 23

B. Permainan Bola Voli 25

1. Hakekat Permainan Bola Voli 25

2. Teknik Dasar Permainan Bola Voli 26

3. Service Bawah 29

4. Passing Bawah 29

C. Permainan Sepak Bola 29

1. Hakekat Permainan Sepak Bola 29

2. Teknik Dasar Pada Permainan Sepakbola 30

3. Passing 32

4. Dribbling 33

BAB IV MODEL PEMBELAJARAN PERSONALIZED SYSTEM OF INTRUCTION (PSI) 
A. Hakikat Model Pembelajaran PSI (Personalized System Of Intruction)

B. Karakteristik Model Personalized System Of Instruction (PSI)

C. Tujuan Model Pembelajaran PSI (Personalized System Of Intraction)

D. Efektifitas Model Pembelajaran PSI (Personalized System Of Intraction)

E. Prosedur dan Langkah-langkah Pembelajaran Model PSI (Personalized System Intraction)

BAB V MODEL SAINTIFIK

A. Hakikat Model Pembelajaran Saintifik 43

B. Langkah-langkah Penerapan Model Saintifik 44

BAB VI MULTIMEDIA 46

A. Pengertian Multimedia 46

B. Karakteristik dan Fungsi Multimedia Pembelajaran 46

C. Komponen Multimedia $\quad 47$

D. Dampak Multimedia dalam Pembelajaran 47

BAB VII APLIKASI "POJOK PENDIDIKAN JASMANI” 48

BAB VIII GAYA BELAJAR 55

A. Definisi Gaya Belajar 55

B. Macam-macam Gaya Belajar 56

C. Gaya Belajar Visual 56

D. Gaya Belajar Auditorial 57

E. Gaya belajar Kinestetik $\quad 57$

F. Ciri-Ciri Gaya Belajar 58

$\begin{array}{ll}\text { DAFTAR PUSTAKA } & 61\end{array}$ 


\section{DIGITALISASI PEMBELAJARAN PENDIDIKAN JASMANI DI ERA 4.0}




\section{BAB I \\ PENDAHULUAN}

\section{A. Perkembangan Pembelajaran Pendidikan Jasmani}

Revolusi industry 4.0 yang terjadi mulai pada tahun 2010 secara tidak langsung berdampak pada perkembangan dunia pendidikan di seluruh dunia, dimana pada era ini terjadi sebuah pengaksesan data yang tidak terbatas dan penggunaan sebuah teknologi yang relatif cepat dan terus berkembang, bahkan perubahan yang terjadi pada era saat ini menjadi bagian dari perkembangan dan perubahan pada ilmu pendidikan (Kosturos, 2012). Salah satu bukti nyata perkembangan teknologi pada praktik pendidikan yaitu dengan diluncurkannya program pemerintah terkait Buku Sekolah Elektronik (BSE), Irawan, Sari, \& Setyoningrum, (2011) menegaskan bahwa BSE ditujukan untuk pengoptimalan pembelajaran di era millennial. Sukiyandari, Soegiyanto \& Rustiana (2012) mengungkapkan bahwa perkembangan teknologi harus seiring dengan pemanfaatannya secara optimal, karena penggunaan teknologi secara optimal dalam dunia pendidikan akan memberikan pengaruh pada pencapaian hasil belajar siswa. Selain itu, pemanfaatan teknologi secara optimal akan memberikan manfaat yang lebih tinggi dalam menciptakan proses pembelajaran yang melibatkan guru dan siswa sehingga semua potensi yang ada tereksplorasikan dengan baik. (Darmawan, 2012) mengungkapkan bahwa terdapat keuntungan dari pemanfaatan teknologi di dalam proses pembelajaran yaitu: Pertama, sebagai pendorong semua komunitas dalam pembelajaran (termasuk guru) untuk lebih apresiatif dan proakif dalam memaksimalkan potesi pendidikan, kedua memberikan kesempatan yang luas kepada peserta didik dalam memanfaatkan setiap potensi 
yang ada, yang dapat diperoleh dari sumber-sumber yang tidak terbatas. Pembelajaran berbasis teknologi sudah banyak diterapkan dalam berbagai mata pelajaran, bahkan saat ini sudah mulai dipraktikan dalam pembelajaran pendidikan jasmani dan olahraga yang diselenggarakan di sekolah.

Pendidikan jasmani yang diselenggarakan di sekolah, pada dasarnya untuk melibatkan para siswa dan memberikan bekal kepada mereka agar kelak memiliki kemampuan dalam aktivitas gerak, selain itu untuk membekali pada kemapuan menerapkan hidup sehat, perkembangan mental serta kemampuan dalam berinteraksi social (Hanansyah \& Ginanjar, 2019). Gani \& Soegiyanto (2012) pendidikan jasmani merupakan salah satu bagian integral dari suatu proses pendidikan secara utuh yang bertujuan untuk mengembangkan aspek kesehatan, kebugaran jasmani, keterampilan sosial, dan moral dari aktivitas gerak yang dilakukan. Suherman, (2009) menjelaskan bahwa pembelajaran gerak adalah suatu proses pendidikan gerak yang melibatkan siswa secara keseluruhan melalui kegiatan bermain, olahraga, dan kegiatan fisik serta dilakukan secara terstruktur dan terprogram untuk memberikan bekal hidup jangka panjang pada siswa berupa kemampuan hidup aktif, kemampuan berfikir dan kemampuan sosial. Husdarta; Saputra (2000) dampak dari pembelajaran gerak di sekolah bertujuan untuk membentuk dan memunculkan ketertarikkan para siswa pada aktivitas gerak serta mengenal secara mendalam mengenai gerak serta memiliki keyakinan untuk mau bergerak. Dacica (2015) mengungkapkan bahwa pendidikan jasmani merupakan salah satu unsur terpenting dalam membangun generasi muda dalam hal membangun fisik, gerak dan kepribadian. SHAPE (2015); Position Statement Comprehensive School Physical Activity Programs: Helping All Students Log 60 Minutes of Physical Activity Each Day The Need for Physical Activity (2013) mengungkapkan bahwa pembelajaran gerak di sekolah tidak lain bertujuan untuk memberikan kesadaran kepada para siswa dengan cara 
memberikan pemahaman, keterampilan dan kepercayaan diri untuk menikmati aktivitas fisik dalam jangka waktu yang Panjang. Bahkan pembelajaran pendidikan jasmani yang di selenggarakan di sekolah saat ini sudah mulai melibatkan berbagai macam bentuk teknologi seperti dengan memanfaatkan video pembelajaran melalui laptop atau smartphone (Cahyati \& Suherman, 2014), ( Setyawan, 2016).

Penggunaan video dalam pembelajaran melalui laptop atau smartphone telah menjadi wahana pembelajaran berbasis teknologi yang digunakan dalam pembelajaran pendidikan jasmani dan olahraga di sekolah-sekolah, khususnya untuk menyampaikan informasi atau pesan, Mohnsen \& Thompson (2013) menyatakan bahwa pengunaan video dalam proses pembelajaran mampu memberikan banyak manfaat diantaranya dapat dipergunakan untuk menyampaikan informasi. Proses pembelajaran pada pendidikan jasmani dan olahraga menekankan pada partisipasi siswa untuk melakukan aktivitas gerak dan keterampilan sebagaimana konsep gerak dan keterampilan tersebut. Akan tetapi pada era sekarang, pembelajaran gerak dapat diperoleh dari produk teknologi berupa pedoman belajar berbasis teknologi, seperti video pembelajaran. Pengunaan teknologi di dalam pembelajaran pendidikan jasmani di era 4.0 seperti penggunaan video you tube dengan penggunaan sebesar 41,5 $\%$, video what apps sebesar $48 \%$, dan e-modul sebesar 10,5\%. Selain itu sebanyak $72.4 \%$ guru di tingkat SMA, 16.1\% ditingkat SMP, dan $11.5 \%$ di tingkat sekolah dasar mereka sudah terbiasa memanfaatkan berbagai macam teknologi untuk menunjang serta membantu dalam mengeffektifkan pembelanjaran. Eberline \& Richards (2013) menjelaskan bahwa teknologi memiliki potensi untuk memfasilitasi pembelajaran yang lebih efektif dalam pendidikan jasmani. Penelitian dibidang penerapan teknologi sudah banyak dilakukan, bahkan kehadiran teknologi dalam pembelajaran menjadi suatu hal yang penting untuk diterapkan, termasuk 
bagi guru pendidikan jasmani dalam proses pembelajaran gerak (Juniu, 2011).

Pembelajaran gerak yang dilaksanakan di sekolah pada dasarnya memiliki target pencapaian berupa siswa mampu memahami dan mempraktekkan berbagai gerak dasar yang teraplikasikan ke dalam beberapa cabang olahraga, diantaranya penguasaan gerak dasar pada permainan bola besar, permainan bola kecil, aktivitas uji diri, aktivitas aquatik dan aktivitas ritmik (Kemendikbud, 2013). Permainan bola besar baik permainan bola basket, permainan sepakbola dan permainan bola voli pada dasarnya masih menjadi pembelajaran gerak yang digandrungi dan diminati oleh para siswa dibandingkan dengan materi pembelajaran gerak yang lainnya (Juditya, 2018); Agusni Zakaria, dkk (2018) minat siswa pada pembelajaran basket sebesar $48 \%$ dan volley sebesar $36 \%$, namun hal ini tidak sejalan dengan pencapaian hasil belajar yang belum sepenuhnya mampu mencapai nilai KKM yang ditentukan oleh pihak sekolah khususnya di kota Cimahi sebesar 75, bahkan hanya terjadi peningkatan penguasaan gerak sebesar 29,5\% (Wardana n.d.). Selain itu, pencapaian hasil belajar pendidikan jasmani khususnya di kota cimahi belum mengalami keoptimalan dalam pencapaiannya (Juditya dkk.,2018).

Banyak hal yang dapat membantu dalam pengoptimalan pencapaian hasil belajar gerak, menurut Slameto (2010); Dimyati dan Mudjiono (2006) keoptimalan hasil belajar tidak terlepas dari adanya keterlibatan antara guru, siswa dan lingkungan belajar, bahkan Casey \& MacPhail (2018) penerapan model pembelajaran yang diterapkan oleh guru mampu memberikan kemudahan pada siswa dalam pencapaian hasil belajar begitupun pada pembelajaran fisik perlu adanya keterlibatan model pembelajaran di dalamnya. Joyce, B. and Weil, M (1986) dalam Juliantine (2013) "model pembelajaran yang diterapkan secara benar akan membantu siswa dalam memperoleh informasi, ide, cara berfikir, keterampilan dan cara dalam 
mengekspresikan diri dalam pembelajaran". Terdapat beberapa model pembelajaran yang diterapkan di Indonesia, diantaranya model problem based learning, project based learning, discovery learning dan yang terakhir inquiry model dan semuanya menekankan pada proses pembelajaran yang bersifat saintifik (Pendidikan \& Kebudayaan, 2014). Untuk menunjang hal tersebut, maka lahirlah sebuah model pembelajaran berbasis saintifik yang dianggap mampu meningkatkan hasil pembelajaran Prabowo (2015); Treagust, Chittleborough, \& Mamiala, (2002) model pembelajaran saintifik lebih membantu siswa dalam mengembangkan konsep pembelajaran secara ilmiah yang dilakukan oleh siswa. Model pembelajaran berbasis saintifik menjadi salah satu model pembelajaran yang diterapkan oleh guru pendidikan jasmani mulai dari tahun 2013 (Permendikbud, 2013). Model pembelajaran saintifik ini merupakan salah satu strategi pembelajaran yang mulai di dalam tahapan proses pembelajaran terdapat lima tahapan diantaranya proses pengamatan (Gustiawati, Fahrudin, 2014). Bahkan di dalam penerapannya, beberapa guru pendidikan jasmani menerapkan berbabagi media pembelajaran yang inovatif diantaranya video you tube (Luhsasi \& Sadjiarto, 2017), dengan pengunaanya mampu memberikan banyak informasi kepada siswa (Setyorini, 2016) bahkan memberikan kemudahan kepada siswa untuk memperoleh informasi (Wibawa, 2017) dan mampu meningkatkan ketertarikkan untuk belajar dkk., 2014) selain itu dengan pemanfaatan sebuah video mampu memberikan efek yang sangat kuat kepada siswa untuk mau berpikir atas apa yang sedang dilihat (Berk, 2009). Hitlin P, (2005) sebanyak 78\% pengunaan internet berupa pemanfaatan video you tube merupakan kalangan remaja mulai dari usia 12-17 tahun untuk keperluan pembelajaran di sekolah. Video you tube bukanlah suatu aplikasi video yang baru dan asing bagi para siswa, mereka sudah mengenal dan terbiasa dalam penggunaanya bahkan dianggap sebagai media pembelajaran berbasis video yang 
dapat membantu siswa dalam peningkatan hasil belajar karena penggunaannya mampu menarik perhatian siswa (Lestari, 2013).

\section{B. Model Pembelajaran Yang Effektif}

Peningkatan hasil belajar merupakan satu capaian dari penerapan sebuah model pembelajaran, namun capaian dari suatu proses pembelajaran harus juga mampu menanamkan siswa sebagai individu yang mampu menjadi pembelajar yang sejati dimana siswa mampu berperan aktif di dalam secara utuh selama proses pembelajaran berlangsung. Proses pembelajaran yang menekankan kepada aktivitas siswa sebagai pribadi yang memiliki jiwa pembelajar yang sejati atau pembelajaran yang berpusat pada keaktifan siswa agar siswa memiliki pengalaman dan pengetahuan dari proses pembelajaran yang dilakukan di sekolah, maka perlu adanya penerapan strategi pembelajaran yang diterapkan oleh seorang guru yang mampu menjadikan siswa sebagai pembelajar yang memilki jiwa pembelajar dan memilki kemadirian di dalam pembelajaran. Model pembelajaran personalized system instruction (PSI) merupakan salah satu model pembelajaran yang effektif yang dapat diterapkan oleh seorang guru untuk menjadikan siswa pembelajar yang aktif dan mandiri. Kalaivani dkk., (2014), mengungkapkan bahwa "Personalized system of instruction (PSI) is the one of the recent innovation which has been successfully introduced in higher education to individualize instruction. This system of instruction which is person oriented." Bahkan Metzler (2005) mengungkapkan bahwa "reported the same positive results for the student process, along with a more important finding that the PSI students had significantly higher learning gains over the students who had direct instruction".

Hannon dkk., (2008) model personalized system of instruction (PSI) berpotensi untuk mengembangkan potensi belajar pada siswa seumur hidup. (Fallis, 2013) pembelajaran dengan penerapan model personalized system of instruction 
(PSI) dapat meningkatkan pembelajaran serta keaktifan siswa bahkan mampu meningkatkan percaya diri dan respon yang benar dibandingkan dengan pembelajaran konvensional. Fisher (1979) model ini dirancang untuk membantu siswa berperan aktif selama proses pembelajaran dibandingkan dengan guru, karena selama proses pembelajaran dengan model ini siswa di ajak untuk lebih bisa mengatur pembelajarannya secara mandiri. Keller dalam Fallis (2013) personalized system of instruction (PSI) merupakan strategi pembelajaran yang berbasis individu. Mengapa model personalized system of instruction dikatakan sebagai konsep pembelajaran yang menanamkan siswa menjadi pembelajar yang mandiri, Grant \& Spencer, (2003) mengungkapkan bahwa karena pada prinsipnya model personalized system of instruction memiliki lima komponen yang menjadikan bahwa model personalized system of instruction (PSI) merupakan model pembelajaran yang bersifat mandiri dengan adanya penerapan modul atau buku panduan siswa di dalam proses pembelajaran. Pembelajaran yang menekankan kepada kemandirian dan keaktifitan siswa di dalam proses pembelajaran, bukan berarti seorang guru meninggalkan siswa yang sedang menjalani proses pembelajaran namun siswa melakukan suatu proses peningkatan kemauan dan keterampilan secara sendiri tanpa bantuan orang lain, sehingga siswa tidak bergantung pada guru, pembimbing, teman atau orang lain (Sukiyandari et al., 2012). Mengacu kepada pendapat di atas, dapat disimpulkan bahwa model personalized system of instruction (PSI)merupakan suatu inovasi pada konsep pembelajaran yang menekankan kepada kesuksesan belajar secara mandiri.

Ada beberapa cara yang dapat dilakukan dengan penerapan model personalized system of instruction (PSI) dalam membentuk siswa menjadi pembelajar yang mandiri, pembelajar yang mampu mengeskplor kemampuan dan kreatifitas, dan pembelajar yang mampu mandiri diantaranya dengan penerapan media-media berbasis teknologi seperti 
halnya berbasis web dan berbasis computer. Grant \& Spencer (2003); Rae \& Samuels (2011) menerapkan model personalized system of instruction dengan menggunakan media we-based atau dengan pemanfaatan media berbasis teknologi lainnya; (Pear \& Novak, 1996); (Springer \& Pear, 2008); (Brothen \& Wambach, 1998) computer salah satu bentuk media teknologi yang dapat dijadikan sebagai alat bantu untuk menyampaikan pembelajaran di dalam penerapan model PSI; Cregger dalam (Metzler, M.W 2005) bahwa "design an animated PSI-Computer Assited Instruction (CAI) module for student learning ...", model personalized system instruction (PSI) berbasis Web (Sciamanna dkk., 2005); berbasis computer (Eyre, 2007); (Brothen \& Wambach, 2000); (Springer \& Pear, 2008). Penerapan model PSI berbasis tekhnologi atau multimedia diharapkan kedepannya siswa akan mampu menjadi pembelajar mandiri yang tidak harus bergantung kepada guru untuk mempelajari tugas atau materi pembelajaran, karena semua instruksi pembelajaran sudah tersedia di dalam modul pembelajaran. Namun penerapan model PSI (personalized System Of Instruction) cukup tepat diterapkan mulai pada usia 13 tahun ke atas (Metzler., 2005). Apabila melihat dari berbagai media teknologi yang digunakan sebelumnya pada penerapan model ini, bahan ajar digital melalui smartphone belum tersentuh atau belum pernah diterapkan. Maka dari itulah, hal tersebut yang menjadi fokus pada pembahasan ini yaitu berupa penerapan bahan ajar digital berbasis smartphone android dan hal ini sejalan dengan konsep pembelajaran berbasis e-learning. (Diani, 2015) elearning merupakan suatu aktivitas pembelajaran yang memisahkan siswa dengan ruang atau waktu dan terhubung dengan sebuah teknologi secara online, karena tidak bisa dipungkiri bahwa teknologi sudah menjadi bagian dari kehidupan masyarakat di dunia begitupun di Indonesia bahkan sudah menikmati kecangihan teknologi dalam kehidupan dalam bentuk smartphone atau telepon pintar mulai dari smartphone berbasis android maupun iphone. Hal ini 
sejalan dengan data survey BBC dalam Titting, Fellyson, Hidayah, Taufik, Pramono (2016) mengatakan bahwa jumlah pengguna smartphone berbasis android sebesar $52.20 \%$ pada tahun 2015 dan disusul oleh apple 33.40\%, Blackberry 9.50\% dan Microsoft 3.60\% dan Symbian 3.60\%, berdasarkan data tersebut sudah dapat kita simpulkan bahwa mayoritas masyarakat di Indonesia mempergunakan smartphone dengan berbagai jenis IOS. Penggunaan smartphone berbasis android sudah banyak dipergunakan oleh kalangan siswa di berbagai level pendidikan, baik dipergunakan untuk media pertemanan sampai pada pemanfaatan smartphone berbasis android dalam proses pembelajaran, Titting dkk., (2016) mengungkapkan bahwa ketertarikkan siswa pada media smartphone berbasis android sebesar 95\%; bahkan dengan penggunaan media pembelajaran media audio visual akan memberikan dampak yang lebih besar terhadap kemampuan siswa di dalam mengingat dan menyimpan pesan dari media yang digunakan dibandingkan dengan penggunaan media audio maupun visual di dalam menyampaikan materi pembelajaran, (Jasmani, Keolahragaan, Jasmani, \& Keolahragaan, n.d.) pembelajaran menggunakan media audio visual maka kemampuan daya ingat dalam meneriman pesan sebesar $50 \%$ dan apabila kurang dari 3 hari sebesar 85\% sedangkan lebih dari 3 hari menjadi sebesar $65 \%$ dalam kemampuan menyimpan pesan. Roberts., (1978) model PSI dapat diterapkan di berbagai tingkat pendidikan dan mampu memfasilitasi berbagai karakteristik siswa di dalam pembelajaran.

Karakterisik siswa merupakan salah satu faktor pembelajaran yang bersifat internal, karakteristik yang dimiliki oleh para siswa diantaranya yaitu gaya belajar. Papilaya \& Huliselan (2016); Poter \& Hernacki, (2015) menjelaskan bahwa: "Penunjang lain dalam pencapaian hasil belajar siswa adalah gaya belajar yang terbagi menjadi gaya belajar visual, auditory, dan kinestetik, gaya belajar seseorang merupakan kombinasi dari menyerap informasi dengan 
mudah dan kemudian mengatur serta mengolah informasi tersebut". Gaya belajar merupakan suatu karakteristik dari setiap individu dalam menerima dan mengelola informasi untuk ditindak lanjuti (Ames, 2003). Gaya belajar merupakan suatu cara siswa dalam merespon dan menggunakan rangsangan dalam pembelajaran (Harris dkk., 2003); gaya belajar adalah cara seseorang dalam menerima, memahami dan memproses serta menyimpan informasi (Singh., 2016). Goldfinch \& Hughes (2007) gaya belajar akan berdampak pada kinerja siswa. Gaya/tipe belajar yang dimiliki oleh siswa akan berpengaruh kepada pencapaian hasil belajar (Tanta, 2010); (Zahri, Yusuf, \& S, 2017) mengungkapkan bahwa gaya belajar memberikan pengaruh sebesar $73 \%$ terhadap pencapaian hasil belajar, Bire \& Geradus., (2014) gaya belajar visually memberikan pengaruh terhadap prestasi belajar sebesar $26.4 \%$, gaya belajar auditory sebesar $24.2 \%$ dan gaya belajar kinestetik sebesar 26.2\%. Gaya belajar siswa mampu memberikan pengaruh yang cukup signifikan pada pencapaian hasil belajar yang effektif (Alkhateeb \& Mji, 2009); (Zahri et al., 2017); (Rijal \& Bachtiar, 2015). Gaya/tipe siswa dalam belajar terbagi menjadi tiga tipe yaitu gaya/tipe belajar melalui proses mendengar, gaya/tipe belajar melalui proses melihat dan gaya/tipe belajar melalui proses mendengar dan melihat, sejalan dengan ungkapan Poter \& Hernacki., (2015) mengungkapkan bahwa gaya belajar terbagi menjadi tiga tipe yaitu gaya belajar auditory dimana siswa yang memiliki gaya belajar ini memiliki kencenderungan cara belajarnya dengan cara mendengar, gaya belajar visually memiliki kencenderungan cara belajarnya dengan cara melihat dan gaya belajar kinestetik memiliki kencenderungan cara belajarnya dengan cara melihat dan mendengar. Maka dari itu proses pembelajaran dengan memanfaatkan unsur teknologi seperti halnya modul berbasis android yang mempergunakan internet di dalam proses pembelajarannya diharapkan mampu memfasilitasi siswa belajar sesuai dengan kebutuhan dan gaya/tipe siswa dalam proses belajar. Munir (2012) 
menjelaskan pada preferred modality theory bahwa pada dasarnya siswa di dalam proses pembelajaran memiliki kecenderungan modalitas belajar yang berbeda, ada siswa dengan modalitas pemahaman melalaui aktivitas mendengar, ada juga siswa dengan modalitas pemahaman melalui aktivitas melihat dan sebagian lagi ada siswa dengan memiliki modalitas pemahaman aktivitas melalui mendengar dan melihat.

Mengacu kepada pemaparan di atas, bahwa proses pembelajaran penguasaan gerak pada anak SMP pada dasarnya bergantung pada bagaimana seorang guru harus mampu menerapkan strategi pembelajaran yang diterapkan, baik dalam penggunaan model pembelajaran, metode pembelajaran maupun pendekatan pembelajaran. Dengan penerapan model pembelajaran siswa akan cenderung lebih aktif di dalam proses pembelajaran, dimana siswa dituntut untuk terlibat secara langsung dengan melibatkan proses berfikir dan siswa cederung akan secara langsung memperoleh pengalaman dan pemahaman dari proses pembelajaran. Sepeti halnya dengan penerapan model PSI (Personalized System of Instruction) siswa dituntut untuk belajar secara mandiri didampingi dengan adanya penerapan modul belajar, dengan proses pembelajaran yang aktif maka secara tidak langsung siswa akan memperoleh pengalaman dan pemahaman gerak dari proses belajarnya mulai dari membaca, menganalisis, mencerna dan melakukan tugas gerak sesuai dengan apa yang tertera pada modul di dalam penerapan personalized system of instruction (PSI) secara mandiri. Hal ini sejalan dengan konstruktivisme theory dan personalized theory yang di menjadi dasar pada model tersebut, dimana dalam kedua teori tersebut dijelaskan bahwa pengetahuan dan pemahaman siswa diperoleh dari proses pembelajaran yang menuntut siswa untuk terlibat secara aktif dari sebuah proses pengamatan dan pengalaman nyata dalam proses pembelajarannya secara mandiri. Namun penerapan model pembelajaran tidak selamanya dapat memberikan 
pengaruh secara langsung kepada pencapaian hasil belajar, karena dalam hal ini ada faktor internal dari diri siswa yang mampu mempengaruhi pencapaian hasil belajar gerak. Salah satu faktor internal yang mempengaruhi pencapaian hasil belajar gerak yaitu gaya belajar yang dimiliki oleh masingmasing siswa. Pencapain hasil belajar menurut teori slameto bahwa terdapat tiga faktor yang akan membantu siswa dalam mencapai hasil belajar yaitu faktor guru, faktor siswa dan faktor lingkungan belajar (Slameto, 2005). 


\section{BAB II \\ PENDIDIKAN JASMANI}

\section{A. Hakikat Pendidikan Jasmani}

Dalam perkembangannya, pendidikan jasmani pertama kali dikemukakan oleh William yang menggungkapkan bahwa pendidikan jasmani adalah proses pembelajaran yang dilakukan melalui jasmani. Schools, (1937) Pendidikan jasmani harus bertujuan untuk memberikan kontribusi semaksimal mungkin pada pengembangan potensi individu yang optimal dalam semua fase kehidupannya termasuk kemampuan terbaiknya untuk menyesuaikan diri dengan lingkungannya, (Meredith, 1929) Pendidikan jasmani pada dasarnya bertujuan untuk melakukan suatu proses pendidikan, dimana setiap siswa belajar dari pengalamannya pada setiap aktivitas berupa permainan yang dikembangkan dalam program pembelajaran jasmani. Lutan, (2002) mengatakan bahwa:

“Pembelajaran gerak yang melibatkan raga merupakan salah satu proses pendidikan yang dilakukan pada anak-anak lewat kegiatan belajar gerak, membentuk kepribadian dan membentuk kebiasaaan untuk hidup sehat. di dalam prosesnya siswalah yang dijadikan sebagai objek belajar dan secara tidak langsung sebagai sentral yang harus memperoleh perhatian."

Suherman, (2015) mengungkapkan bahwa Pendidikan jasmani merupakan suatu proses pendidikan melalui dan tentang gerak. Mengacu pada beberapa pendapat di atas dapat dikatakan bahwa pendidikan jasmani adalah suatu proses pendidikan yang dilakukan secara sadar dan sistematik baik oleh perongan maupun kelompok melalui kegiatan jasmani yang berkelanjutan dalam rangka memperoleh peningkatan kemampuan dan keterampilan 